\title{
Characterization of Biodiesel from Castor Raw Oil
}

\author{
Mohamed S. Abdelfattah $^{\mathrm{a}}$, Osayed S. M. Abu-Elyazeed ${ }^{\mathrm{b}}$, E. AbdElmawla ${ }^{\mathrm{a}}$ and Marwa A. \\ Abdelazeem ${ }^{\mathrm{a}}$. \\ ${ }^{\mathrm{a}}$ Chemistry Department, Faculty of Science, Helwan University, ${ }^{\mathrm{b}}$ Department of Mechanical \\ Power Engineering, Faculty of Engineering -Mataria, Helwan University
}

\begin{abstract}
In the present work, castor bio-diesel (C.B.D)fuel of raw castor oil (Ricinus CommunisL.) was synthesized in the presence of sodium hydroxide $(\mathrm{NaOH})$ as a catalyst. The influence of catalyst concentration on the yield of castor bio-diesel Fuel was studied. Therefore, different physical properties of bio-diesel could be termed as Caster Bio Diesel (C.B.D) was measured according to American Society of Testing Material (ASTM). Also, the chemical composition of bio diesel was determined by using Gas Chromatography, Mass spectrum (GC-MS) and the functional groups using Infra-Red spectrum (IR). Thus, the main conclusion was drived from both physical and chemical investigations that these synthesized bio-diesel could be used as alternative of diesel.
\end{abstract}

Keywords: Castor oil, Bio-diesel, GC-Mass spectrometry, IR-spectroscopy.

\section{Introduction}

Unlike fossil fuels, biodiesel is a renewable source of energy, because it comes from biological sources. On the other hand, fossil fuels come from underground deposits of hydrocarbons which cannot be renewed. Consequently, the significance of bio fuels as an alternative fuel is largely accounted for by its similar power to petrol diesel (High octane number), increased lubricity over petro diesel, compatibility with engine components and most importantly its environmental (reduced emission of green house gases like $\mathrm{CO}_{2}, \mathrm{CO}$ ) and health benefits; being sulphur, aromatics free and biodegradable (Okoro L.N.et.al,2011). Vegetable oils are produced from numerous oil seed crops. Some of these oils have already been evaluated as substitutes for diesel, and gasoline fuels. which include raw sunflower oil.( Cesarn A.S and Batalha,M.O.,2010), blends of raw sunflower, cottonseed, corn, and olive oil with diesel fuel (Idem R.O et.al,1996), cotton seed oil;(Rakopoulos DC,2011); rapeseed oil (Sales A,2011), jatropha oil(Maher K.D and Bressler.,2007), soybean oil methyl ester (Rakopoulos DC et al,2014),

Corresponding author:

Tel.: 01146475234,E-mail address: mabdelfattah_13@yahoo.com (M.S. Abdelfattah). 
catalytic pyrolysis palm oil (Radwan M.S. et al,2012), distilled opium poppy oil and refined rapeseed oil (Sales A,2011), jatropha oil. (Altin R et al, 2001),jojoba oil (Radwan M.S et al., 2012 and Nwafor O, 2000), castor seed (Scoll K and sorenson, 1993) Castor (Ricinus communis L.) is a kind of widely cultivated inexpensive, environmentally friendly and industrial oil plant. (Demirbas A, 2009).

\section{Materials and Methods}

\subsection{Chemicals}

The raw castor oil, Alumina $\left(\mathrm{Al}_{2} \mathrm{O}_{3}\right)$, Sodium Carbonate, Potassium Hydroxide, and Sodium hydroxide.

\subsection{Synthesizing of Castor Bio-Diesel and Measuring Techniques}

The pyrolysis system test bench consists of an oil bath heater, temperature controller, raw oil heating flask, cold water condenser and bio-diesel receiving flask (Abu-Elyazeed O.S.M, 2015) such rig was designed and constructed to operate at certain temperature. The physical properties were performed in the labs of Cairo Oil Refining Company Subsidiary of Egyptian General Petroleum Corporation. Such properties were measured according to (ASTM). Also, the chemical compositions were obtained by using both of (GC-MS) and (IR) spectroscopy. The GC-MS were recorded by using Thermo Scientific Analyzer at the Regional Centre for Mycology and Bio technology, Al-Azhar University. The IR spectra were recorded as $\mathrm{KBr}$ pellets on a Jasco FTIR plus 460 and Pye Unicam SP-1000 spectro-photometer at the Microanalytical Unit, Cairo University.

\section{Results and Discussion}

\subsection{Influence of Catalyst Type on the Yield of Castor Biodiesel}

It is worth to mention that catalytic conversion of raw castor oil yielded castor biodiesel In addition, the rest of the pyrolyzed raw castor oil was bio-mazot with heaviest and black coloured. This experimental work was carried out at atmospheric pressure and a temperature range of 233 to $400^{\circ} \mathrm{C}$ with a constant concentration of each catalyst of $1 \%$ by weight. It was noticed that the volumetric yields of yellowish biodiesels as $12 \%, 27 \%, 36.1 \%, 91.7 \%$ were gained by using alumina, sodium carbonate, potassium hydroxide and anhydrous sodium 
hydroxide as catalysts respectively.It was cocluded that by using $\mathrm{NaOH}$ as a catalyst the highest total yield of biodiesel $91.7 \%$ was obtianed as illustrated in Figure 1.

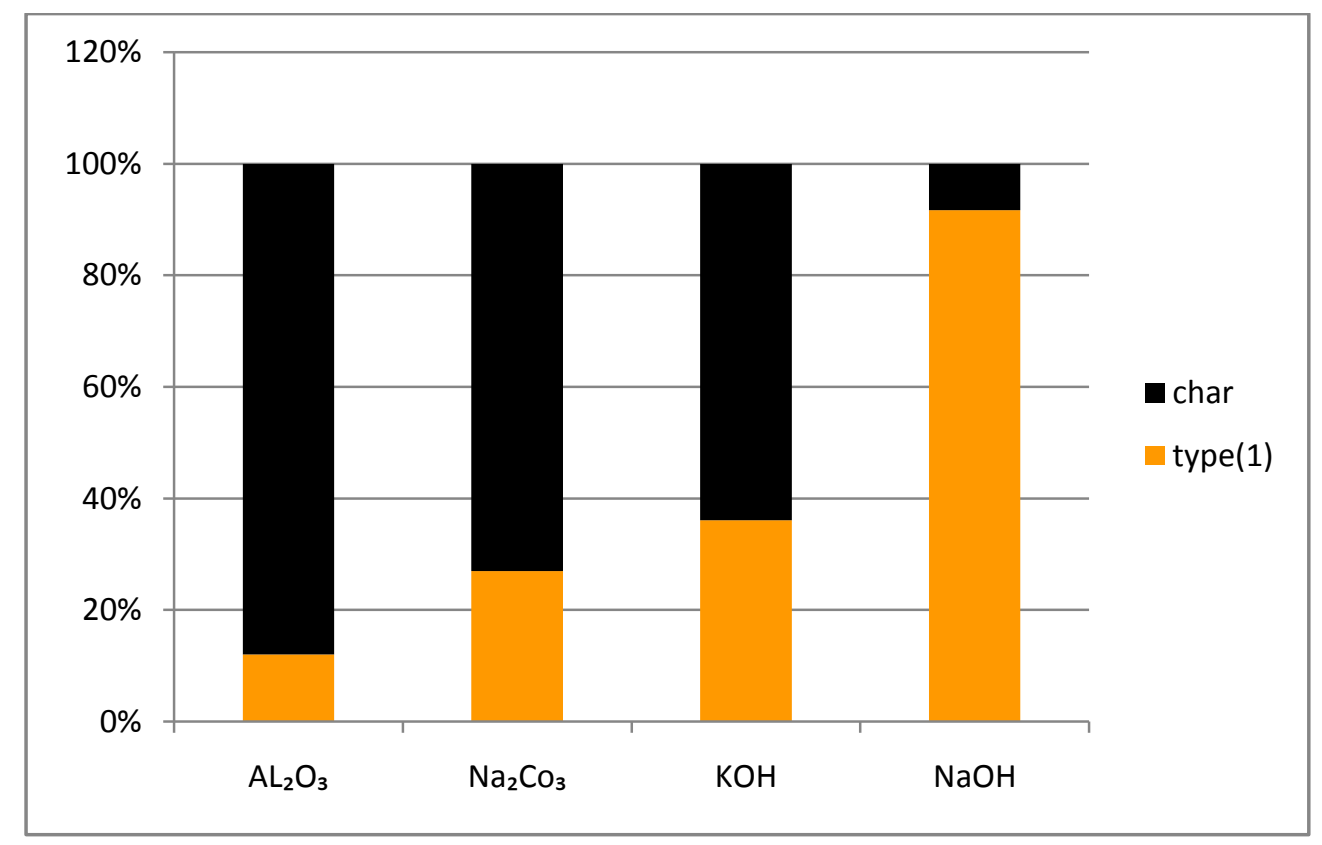

Figure1: Influence of the Catalyst type on the Total Yield of Castor Biodiesel

\subsection{Influence of Catalyst Concentration on Total Yield of Castor Biodiesel}

The Pyrolysis process in the presence of $\mathrm{NaOH}$ as a catalyst due to its high yielding was choosen to show the effect of variation of the concentration of $\mathrm{NaOH}$ on the yield . Thus, different concentrations of $\mathrm{NaOH}$ was applied at atmospheric pressure and temprature range from $233-347^{\circ} \mathrm{C}$ as pyrolysis conditions. Figure 2 showed that the highest yeild was gained in the presence of $1 \%$ by weight of $\mathrm{NaOH}$. Such yield was decreased by incresing and/or lowering of the catalyst concenteration.

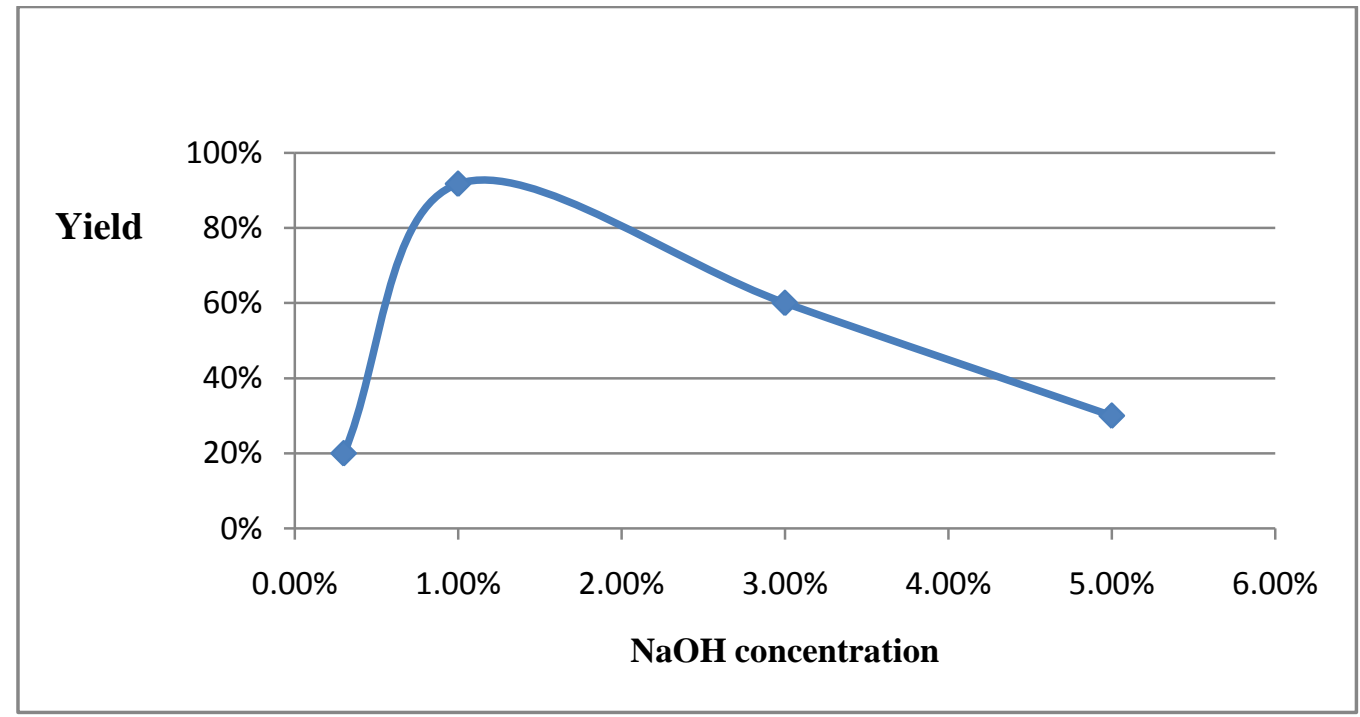


Figure2: Influence of the Catalyst Concentration on the Total Yield of Castor Biodiesel

\subsection{Influence of Catalyst Type on Pyrolysis Temperature Range}

The temperature range of the pyrolysis procees is considered as one of the most important parameters regarding to energy consumption of this procees. Figure 3 illustrates that the variation of the catalyst types affect strongly on the temperature range of the pyrolysis. Such temperature ranges of $233: 347^{\circ} \mathrm{C}, 280: 400^{\circ} \mathrm{C}, 254: 390^{\circ} \mathrm{C}$ and $245: 370^{\circ} \mathrm{C}$ were applied in the presence of anhydrous $\mathrm{NaOH}, \mathrm{Al}_{2} \mathrm{O}_{3}, \mathrm{Na}_{2} \mathrm{Co}_{3}$ and $\mathrm{KOH}$ as catalysts respectively as shown in Figure 3 . Thus it is concloded that the usage of $1 \%$ by weight of $\mathrm{NaOH}$ as a catalyst not only produce the heighest yeild of castor biodiesels but also achieve the most energy saving regarding the pyrolysis process.

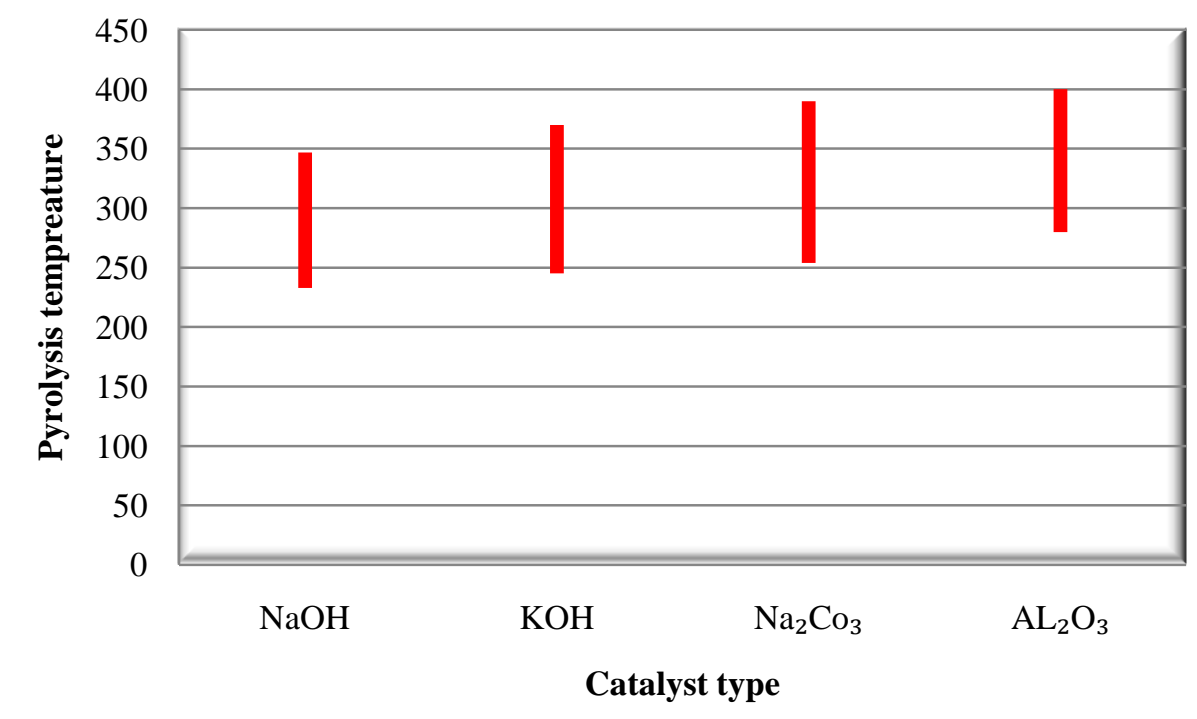

Figure1: Influence of the Catalyst type on Pyrolysis Temperature Range 


\subsection{Physical Characterization of Different Types of Castor Biodiesel}

The physical properties of such raw castor oil are shown in Table 1 . The physical propeities of castor biodiesel was measured according to the ASTM standard as shown in Table 2, the values of these physical properites matches with those found in the literature (Selim et al, 2003) and diesel standards as well. Table 2 illustrates that the denisty of C.B.D was slightely more than that of diesel standard Thus, could lead to complete physical mixing between commercial fuels and castor bio diesel without separation. The kinematic viscosity of C.B.D was within range of diesel standard as shown in Table 2.

Thus, an expected low droplet size of injected this biodisel (Rakopoulos DC et al, 2014). As shown in Table 2, the flash point of C.B.D is $>100^{\circ} \mathrm{c}$, which exceed the minimum value of the diesel standards. Furthermore, the pour point of C.B.D was less than the minimum value of the diesel standard. The distillation temperatures of this biodiesel are an indication for the fuel composition, which is normally difficult to obtain for petro diesel, and specifies the maximum temperature of distillation for $85 \%$ of its components. The presence of high boiling point components in fuels can significantly affect the degree of formation of solid combustion deposits. Moreover; the sulphur contents are undesirable because of its impact on the formation of toxic compounds. Table 2 showed that the sulfur and ash contents of C.B.D were not detected. As shown in Table 2, the carbon residue of biodiesel was higher than that of diesel standard.. However, the most important property is the cetane number. Table 2 shows that the cetane number of C.B.D was higher than diesel standard. Further more, as shown in Table 2, the cupper Cu-strip corrosion of C.B.D was in agreement with those of diesel standard. Finally, Table 2 shows that the calorefic values of C.B.D was higher than the diesel standard.

Table 1. Physical Properties of Raw Castor Oil

\begin{tabular}{|l|c|}
\hline \multicolumn{1}{|c|}{ Property } & Castor oil \\
\hline Viscosity $\left(\mathrm{mm}^{2} / \mathrm{s}\right)$ & 239.39 \\
\hline Density at $15^{\circ} \mathrm{C}(\mathrm{g} / \mathrm{cm} 3)$ & 0.957 \\
\hline Density $20^{\circ} \mathrm{C}(\mathrm{g} / \mathrm{cm} 3)$ & 0.958 \\
\hline $\begin{array}{l}\text { Flash point }( \\
\left.{ }^{\circ} \mathrm{C}\right)\end{array}$ & 310.0 \\
\hline Sulfur $(\%)$ & Nill \\
\hline Copper strip corrosion & 1.0 \\
\hline ASTM color & Yellow \\
\hline
\end{tabular}


Table 2. Physical Chracteristics of Castor Bio-Diesel versus Diesel Standard

\begin{tabular}{|c|c|c|c|c|}
\hline Property & Unit & $\begin{array}{c}\text { Diesel } \\
\text { Standard }\end{array}$ & C.B.D & $\begin{array}{c}\text { Standard } \\
\text { Method }\end{array}$ \\
\hline Density at $23^{\circ} \mathrm{C}$ & $\mathrm{Kg} / \mathrm{l}$ & 0.832 & 0.8700 & $\begin{array}{l}\text { ASTM } \\
\text { D4052 }\end{array}$ \\
\hline Specific Gravity & & 0.85 & 0.8708 & $\begin{array}{l}\text { ASTM } \\
\text { D1298 }\end{array}$ \\
\hline Kinematic Viscosity at $40^{\circ} \mathrm{C}$ & & $1.6-7$ & 4.347 & $\begin{array}{l}\text { ASTM } \\
\text { D7042 }\end{array}$ \\
\hline $\begin{array}{l}\text { Pensky Flash point } \\
\text { Closed cup }\end{array}$ & ${ }^{\circ} \mathrm{C}$ & $\begin{array}{c}\text { Min } \\
55\end{array}$ & $>100$ & ASTM D93 \\
\hline Pour point & ${ }^{\circ} \mathrm{C}$ & $3: 15$ & -39 & $\begin{array}{l}\text { ASTM } \\
\text { D6749 } \\
\end{array}$ \\
\hline $\begin{array}{c}\text { Disttilation } \\
\text { Initial boiling Point } \\
10 \% \text { distillated by volume } \\
50 \% \text { distillated by volume } \\
85 \% \text { distillated by volume } \\
90 \% \text { distillated by volume } \\
\text { Temp of boiling end } \\
\text { The rest }\end{array}$ & $\%$ volume & $\operatorname{Max} 85 \%$ & $\begin{array}{c}68.7 \\
133.2 \\
281.4 \\
- \\
- \\
- \\
20.0 \\
\end{array}$ & ASTM 86 \\
\hline SulfurContent & $\%$ mass & Max1 & 0.00 & $\begin{array}{l}\text { ASTM } \\
\text { D4294 }\end{array}$ \\
\hline Ash & $\%$ mass & Max 0.01 & 0.00 & ASTM482 \\
\hline Carbon Residue & $\%$ mass & Max 0.1 & 1.07 & $\begin{array}{l}\text { ASTM } \\
\text { D4530 }\end{array}$ \\
\hline Cetane Number & & Min 46 & 43.95 & $\begin{array}{l}\text { ASTM } \\
\text { D4737 }\end{array}$ \\
\hline $\mathrm{Cu}$-strip corrosion at $50^{\circ} \mathrm{C}$ for 3 hours & & Max 1 & 1 & ASTM D130 \\
\hline Calorific value & & $\operatorname{Min} 44.3$ & 45.26 & $\begin{array}{l}\text { ASTM } \\
\text { D4868 }\end{array}$ \\
\hline
\end{tabular}

\subsection{Chemical Characterization of C.B.D via GC-MS Spectrometry}

The compounds present in C.B.D were realized by using GC-MS. The results of GC-MS analysis of C.B.D are illustrated in Table3 by considering area percentage, the highest peak areas of total ion chromatogram (TIC) of compounds are ethyl ether; hexane-3-methyl; n- 
nonane; n-heptaldehyde; heptoic acid;1b,5,5,6a-tetramethyloctahydro-6H-indeno[1,2b]oxiren-6-one;1-(2`-nitro-2`propenyl)-cyclo hexene; myristyl chloride; 1-chlorooctadecane; oleic acid; 11-cyclopentylundecanoic acid; preg-4-en-3-one,17à-hydroxy-17á-cyano; 10undecenoic acid ;oxacyclotetradeca-4,11-diyne; 1,3,5 triazine-2,4 diamine -6- chloro $\mathrm{n}$ ethyle; iso chiapin B. The presence of nitrogen compounds and appearance of halogens is attributed to the composition of castor seeds which derives these elements from the soil. The results of castor pyrolysis oil analysed by GC-MS reveal that compounds present are matched with other bio oils given in literature (Singh R.K and Shadangik., 2011).

Table3.GC-Mass Spectrometry Analysis of C.B.D

\begin{tabular}{|c|c|c|c|c|}
\hline RT & Compound Name & Area \% & Molecular Formula & Molecular Weight \\
\hline 3.29 & Ethyl ether. & 17.74 & $\mathrm{C}_{4} \mathrm{H}_{10} \mathrm{O}$ & 74 \\
\hline 3.40 & Hexane-3-methyl & 4.96 & $\mathrm{C}_{7} \mathrm{H}_{16}$ & 100 \\
\hline 5.33 & N-Nonane & 6.50 & $\mathrm{C}_{9} \mathrm{H}_{20}$ & 128 \\
\hline 5.80 & N-Heptaldehyde. & 24.07 & $\mathrm{C}_{7} \mathrm{H}_{14} \mathrm{O}$ & 114 \\
\hline 8.46 & Heptoic acid. & 3.35 & $\mathrm{C}_{7} \mathrm{H}_{14} \mathrm{O}_{2}$ & 130 \\
\hline 8.81 & $\begin{array}{l}\text { 1b,5,5,6a-Tetramethyloctahydro- } \\
\text { 6H-indeno[1,2-b]oxiren-6-one }\end{array}$ & 0.46 & $\mathrm{C}_{13} \mathrm{H}_{20} \mathrm{O}_{2}$ & 208 \\
\hline 9.35 & $\begin{array}{c}\text { 1-(2`-Nitro-2`propenyl)-cyclo } \\
\text { hexene. }\end{array}$ & 0.59 & $\mathrm{C}_{9} \mathrm{H}_{13} \mathrm{NO}_{2}$ & 167 \\
\hline 9.57 & Myristyl chloride & 5.73 & $\mathrm{C}_{14} \mathrm{H}_{21} \mathrm{Cl}$ & 170 \\
\hline 10.95 & 1-Chlorooctadecane & 5.34 & $\mathrm{C}_{18} \mathrm{H}_{37} \mathrm{Cl}$ & 288 \\
\hline 11.06 & Oleic acid. & 2.54 & $\mathrm{C}_{18} \mathrm{H}_{34} \mathrm{O}_{2}$ & 282 \\
\hline 12.29 & 11-Cyclopentylundecanoic acid. & 2.39 & $\mathrm{C}_{16} \mathrm{H}_{30} \mathrm{O}_{2}$ & 254 \\
\hline 12.65 & $\begin{array}{c}\text { Preg-4-en-3-one, } \\
\text { 17à-hydroxy-17á-cyano }\end{array}$ & 0.13 & $\mathrm{C}_{20} \mathrm{H}_{27} \mathrm{NO}_{2}$ & 313 \\
\hline 13.64 & 10-Undecenoic acid. & 6.85 & $\mathrm{C}_{11} \mathrm{H}_{20} \mathrm{O}_{2}$ & 184 \\
\hline 13.83 & Oxacyclotetradeca-4,11-diyne & 0.24 & $\mathrm{C}_{13} \mathrm{H}_{18} \mathrm{O}$ & 190 \\
\hline 15.92 & $\begin{array}{l}\text { 1,3,5 Triazine-2,4 diamine -6- } \\
\text { chloro } n \text {-ethyle. }\end{array}$ & 0.51 & $\mathrm{C}_{5} \mathrm{H}_{8} \mathrm{ClN}_{5}$ & 173 \\
\hline 24.80 & IsochiapinB. & 0.32 & $\mathrm{C}_{19} \mathrm{H}_{26} \mathrm{O}_{6}$ & 346 \\
\hline
\end{tabular}

\subsection{Chemical Characterization of C.B.D by IR Spectroscopy}

The IR spectra of the castor bio diesels showed the functional groups similar to that found in the literature (Scoll K and Sorenson ,1993 ; Demirbas A ,2009Error! Bookmark not defined.; Liu S,2015) which makes it as a good alternative to the traditional fuel. The IR spectra of C.B.D (Table 4) showed an $\mathrm{OH}$ group at $3424 \mathrm{~cm}^{-1} ;=\mathrm{CH}$ stretch of aromatics at $3073 \mathrm{~cm}^{-1}$; $\mathrm{CH}$ aliphatics at $2926 \mathrm{~cm}^{-1}$ and $2857 \mathrm{~cm}^{-1}$. Additionally, the spectra revealed carbonyl group at $1710 \mathrm{~cm}^{-1} ; \mathrm{C}=\mathrm{C}$ at 1645 and $1459 \mathrm{~cm}^{-1}$; and aromatic hydrocarbon carbons at 1459 and $1415 \mathrm{~cm}^{-1} ; \mathrm{C}-\mathrm{O}$ stretch of ether at $1051 \mathrm{~cm}^{-1}$.

Table 4. Functional Groups of IR Spectroscopy of C.B.D 


\begin{tabular}{|c|c|}
\hline Functional Group & Wave Number $\left(\mathbf{c m}^{-1}\right)$ \\
\hline O-H stretching & 3424.96 \\
\hline =CH stretch of aromatics & 3073 \\
\hline CH aliphatic & 2926.45 and 2857.96 \\
\hline C=O carbonyl group & 1710.55 \\
\hline C=C & 1645.38 \\
\hline C-C stretching & 1459.85 and 1415.49 \\
\hline C-O stretch of ether & 1051.01 \\
\hline Opp CH bending & 725.104 \\
\hline
\end{tabular}

\section{Conclusion}

The different chemical and physical properties of castor bio-diesel were measured and the resulted bio-diesel appears to be potentially useful for power production, since its calorific value similar to petroleum fuels used commercially. Thus, this bio diesel can be used directly in industrial burning equipped to handle these types of fuels or used as a blend to improve fuel quality.

\section{References:}

Abu-Elyazeed ,O.S.M., "On the ignition delay of two types of Castor oil bio-diesel using shock tube experiments”, Fuel,(144),157-163, (2015).

Altin R; Cetinkaya S and Yuecesu H; "The potential of using vegetable oil fuels as fuel for diesel engines”, Energy Conversion \& Management, 42(5), 529-38,( 2001).

Atabania, A.E., Silitonga ,A.S., Badruddina, I.A., Mahliaa ,T.M.I., Masjukia, H.H., Mekhilefd ,S., "A comprehensive review on biodiesel as an alternative energy resource and its characteristics”, Renewable and Sustainable Energy Reviews, (16) , 2070- 2093, (2012).

Cesarn ,A.S.and Batalha M.O., "Biodiesel production from castor oil in Brazil”, Energy Policy, (38), 4031-4039, (2010).

Conceicao, M.M., Candeia, R.A., Silva,F.C., Bezerra ,A.F., Fernandes Jr.V.J and Souza A.G., "Thermo analytical characterization of castor oil biodiesel", Renewable and Sustainable Energy Reviews,(11),964-975,( 2007).

Demirbas ,A., "Progress and recent trends in biodiesel fuels”, Energy Conversion and Management , (50), 14-34,(2009).

Idem R.O., Katikaneni S.P.R., Bakhshi N.N., "Thermal cracking of canola oil: reaction products in the presence and absence of steam”, Energy Fuels 10 (6), 1150-1162, (1996).

Maher K.D and Bressler D.C.,"Pyrolysis of triglyceride materials for the production of renewable fuels and chemicals”, Bio resource Technology,(98), 2351-2368, (2007).

Kumar ,M, Ramesh,A, and Nagalingam, B, "Experimental investigations on a jatropha oil methanol dual fuel engine”, SAE 2001-01-0153, World Congress, (2001). 
Liu ,S., Zhu ,Q., Guan ,Q., He L and Li W. , “Bio-aviation fuel production from hydro processing castor oil promoted by the nickel-based bi functional catalysts ", Bio resource Technology,( 183), 93-100,(2015).

Nwafor, $\mathbf{O}$, "Effect of advanced injection timing on the performance of rapeseed oil in diesel engines", Renewable Energy, 21, 433-44,( 2000).

Okoro, L.N., Belaboh, S.V., Edoye, N.R and Makama B.Y. ,."'Synthesis, Calorimetric and Viscometric Study of Groundnut oil Biodiesel and Blends”, Res. J. Chem. Sci, 1(3),(2011).

Radwan M.S., Ismail M A, El-Feky ,S.M.S. and Abu-Elyazeed O.S.M., “Jojoba Methyl Ester as a Diesel Fuel Substitute: Preparation and Characterization”, Applied Thermal Engineering, 21, 314-322, (2007).

Radwan ,MS, Elfeky SMS, and Abu-Elyazeed O.S.M.,"An Investigation on Abnormal Combustion, Emissions and Performance of Jojoba Bio-Gasoline and Its Blends with gasoline in Spark Ignition Engines", SAE International, 2012-01-1599,( 2012).

Rakopoulos ,DC, Rakopoulos ,CD, Giakoumis ,EG, Dimaratos AM, and Founti AM, "Comparative environmental behaviour of bus engine operating on blends of diesel fuel with four straight vegetable oils of Greek origin: Sunflower, cottonseed, corn and olive”, Fuel, 11 (90), 3439-3446, (2011).

Rakopoulos DC, Rakopoulos CD, Giakoumis EG, Papagiannakis RG, and Kyritsis DC, "Influence of properties of various common bio-fuels on the combustion and emission characteristics of high-speed DI (direct injection) diesel engine: Vegetableoil, bio-diesel, ethanol, n-butanol, diethyl ether", Energy,(73), 354-366, (2014).

Sales A, "Production of biodiesel from sunflower oil and ethanol by base catalyzed transesterification”, MSc thesis, Royal Institute of Technology (KTH), Stockholm, Sweden, (2011).

Scoll ,K, and Sorenson, S, “Combustion of soybean oil methyl ester in a direct injection diesel engine”, SAE paper, 930934, (1993).

Selim, MYE; Radwan ,MS; and Elfeky, SMS, "Combustion of jojoba methyl ester in an indirect injection diesel engine”, Renewable Energy, 28, 1401-1420, (2003).

Singh,R.K and ShadangiK,P., "Liquid fuel from castor seeds by pyrolysis", Fuel, (90), 2538-2544,( 2011).

Warra ,A.A.,"Physico-Chemical and GC/MS Analysis of Castor Bean (Ricinus communis L.) Seed Oil”, Chemistry and Materials Research, 2 (7), 56-60, (2015).

Zaher, F.A., Taman, A.R., "Thermally decomposed cottonseed oil as a diesel-engine fuel", Energy Sources ،15 (3), 499-504, (1993). 


$$
\text { الملخص العربي }
$$

$$
\text { توصيف الوقود الحيو ي من الخروع الخام }
$$

محمد صالح عبد الفتاح' ،اسيد سيد محمد ابو اليزيدب،ابتسام عبد المولي'و مروة احمد عبد العظيم' .

'قسم الكيمياء،كليه العلوم،جامعه حلو ان; بقسم هندسه الطاقه الميكانيكيه،كليه الهندسه ــالمطريه،جامعه حلوان.

علي خلاف الوقود الحفرى فالوقود الحيوي يعتبر مصدر متجدد للطاقه، وذلك لان الحصول عليه يتم من المصادر البيولوجيه. علي الصعيد الاخر الوقود الحفري مصدره الترسيبات الارضيه للهيدروكربونات وهي غير متجدده وبناء علي ذلك فان التركيز علي الوقود الحيوي كبديل للوقود الحفري راجع لكون الطاقه الحر اريه الناتجه عنه مماتله لتللك الناتجه عن الوقود الحفري ،كماانها متو ائمه مع مكونات المحرك و الاكثر اهميه من ذللك انها تحافظ علي البيئه من حيث تقليل انبعاثات ثاني اكسيد الكربون واول اكسيد الكربون وفو ائده للصحه العامه كونه خالي من الكبريت و المركبات الاروماتيه الي جانب انه قابل للتحلل.

الزيوت النباتيه تنتج من عدد هائل من بذور الحبوب وبعض منها استخدم كبديل لزيوت للديزل والبنزين وتضم زيت عباد الثمس الخام، اضافات من زيت عباد الثمس وزيت بذرة القطن وزيت الزيتون مع الديزل ، زيت بذره القطن، زيت اللفت الخام، استر ات فول الصويا، زيت النخيل المتحلل حراريا، زيت نفط الخشخاش المقطر زيت الجنروفا، زيت الجوجوبا وزيت بذور الخروع وبالنسبه الي الخروع محل الدر اسه فهو نبات زيتي واسع الانتشار ،غير مكلف كماانه صديق للبيئه. ومن خلال هذه الدر اسه تم تخليق الوقود الحيوي من زيت الخروع الخام في وجود عامل حفاز (هيدروكسيد الصوديوم) ولقد تم حساب كميه الوقود الناتج في وجود نركيزات مختلفه من العامل الحفاز بناء علي مقارنه الكميات الناتجه تم تحديد افضل تركيز للعامل الحفاز للحصول علي اعلي كميه من الوقود كما تم توصيف الوقود الناتج من الخروع بعد قياس الخواص الكيميائيه الي جانب قياس الخواص الفيزيائيه المختلفه باستخدام جهاز الكروماتوجرام و التحليل الطيفي بالاشعه فوق الحمر اء. النتائج التي تم الحصول عليها اوضحت ان القيمة الحراريه للوقود الناتج تتيح استخدامه كمصدر للطاقه وكبديل للوقود الحفري ، ويمكن استخدامه في محركات الاحتراق الداخلي وغرف احتراق المحركات و التوربينات و الغلايات. 